Çukurova Üniversitesi Mühendislik Mimarlık Fakültesi Dergisi, 35(2), ss. 295-309, Haziran 2020

Çukurova University Journal of the Faculty of Engineering and Architecture, 35(2), pp. 295-309, June 2020

\title{
Dalga Yükü Altında İskele Tipi Yapılarda Kullanılan Çakma Çelik Kazık Sistemlerin Davranıșı
}

\author{
Münire FINDIK ${ }^{* 1}$, İ. Devran ÇELIKK ${ }^{1}$, S. Nilay KESKİN ${ }^{1}$, Yusuf ÖZTÜRK ${ }^{1,2}$

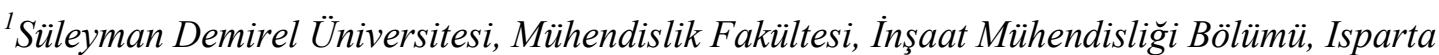 \\ ${ }^{2}$ Isparta Uygulamalı Bilimler Üniversitesi, Senirkent Meslek Yüksekokulu, İşaat Teknolojisi \\ Bölümü, Isparta
}

Geliş tarihi: $14.10 .2019 \quad$ Kabul tarihi: 30.07 .2020

\section{$\ddot{O} z$}

Jeopolitik değer açısından üç tarafı denizlerle çevrili olan ülkemizde liman, iskele ve rıhtım yapıları ile ilgili çalışmalar hız kazanmıştır. Ülkemiz jeolojik ve jeofizik açıdan aktif fayların bulunduğu deprem kuşağında yer almaktadır. Özellikle sismik bölgelerdeki kıyı ve liman yapılarında depreme dayanıklı tasarım ve dizayn aşamalarında Demiryolları, Limanlar ve Hava Meydanları (DLH) Genel Müdürlüğü 2008 yılında, "Kıyı ve Liman Yapıları, Demiryolları ve Hava Meydanı İnşaatlarına İlişskin Deprem Teknik Yönetmeliği” kapsamında verilen teoriler ve formüller kullanılmaktadır. Bu çalışmada, kum zemine oturan kazıklı iskele yapısı üzerine çalışılmışıtır. Farklı kazık çaplarında ve DLH 2008'de tavsiye edilen 4D-8D aralıklarla yerleştirilerek çeşitli modeller oluşturulmuştur. Modellemeler, Sap2000 bilgisayar programı ile yapılmıştır. Kazıklı iskele yapısı için tüm kazık ve üst yapı elemanları ile ilgili detaylı bilgilere yer verilmiștir. Çalışılan modeller için, Zemin durumuna ve değișen dalga periyotlarına göre ideal kazık çapı ve aralı̆̆ına dair sonuçlar grafiklerle sunulmuştur.

Anahtar Kelimeler: İskele yapıları, Kazıklı temeller, Dinamik analiz

\section{Behavior of Pile Steel Pile Systems used in Pier Structures Under Wave Load}

\begin{abstract}
In our country that is surrounded by seas on three sides, harbor, pieranddock structures has gained importance in terms of geopolitical value. Our country is located in theearth quake zone where geologically and geophysically active tectonic faultsreside. Especially in seismic zones, earthquakeresistant design and application are important forcoast a land port structures. The theories and formulas given within the scope of DLH 2008 seismic technical regulations of Coastal and Harbor Structures, Railways and Airport Constructions, are used in the design and design stages. In this study, piled pier structure on sand ground has been studied. Various models with different pile diameter sizes have been created. Different layouts are formed with 4D-8D intervals as recommended in DLH 2008. Sap2000 v. 20 computer program is used for modeling. Detailed in formation regarding the piled scaffolding structure is given. The results of the ideal pile diameter and spacing according to soi lconditions and changing wave periods are presented in the graphs.
\end{abstract}

Keywords:Pier structures, Pile foundations, Dynamic analysis

*Sorumlu yazar (Correspondingauthor) : Münire FINDIK, mnr.dikmen@gmail.com 


\section{GíRİş}

Teknolojinin son 50 yılında yaşanan gelişmeler neticesinde, ülkeler arasındaki ithalat ve ihracat oranları önemli ölçüde artmıştır. İthalat ve ihracat faaliyetlerinin artışı, farklı taşımacılık sistemlerinin gelişmesine sebep olmuştur. Ekonomik olarak uygun olması ve taşıma kapasitesinin fazla olmasından dolayı deniz taşımacılığı, dünya ticaretinde en çok tercih edilen ve ülkelerin ekonomik gelişmelerinde etkin rol oynayan lojistik sistemdir. Bir yarımada ülkesi olarak bu gelişmeler bizimde modern liman ve tersane tesislerine olan ihtiyacımızı artırmıştır.

Limanlar; gemilere dalga, akıntı, firtına ve buz gibi çevresel etkenlere karşı koruma sağlayan, kıyı yanaşma yapılarına gemilerin ve diğer deniz taşıma araçlarının yanaşıp bağlanabileceği veya demirleyebileceği olanakları sunan, tekne ile kıyı arasında gerekli yük, insan nakli ve muhafazası için tesisler barındıran, sınırlandırılmış kara ve deniz alanları olarak tanımlanırlar [1].

Kıyı yanaşma yapılarının başlıcaları: iskele, rıhtım ve dolfenlerdir. İskeleler, kıyı çizgisine dik veya belirli bir açı ile bulunan, bir ucu kıyı ile bağlantılı yapılardır. Rihtımlar, iskelelerin aksine kıyıa paralel olarak yapılan ve istinat yapısı görevi de gören kıyıya bitişik yapılardır. Dolfenler ise, gemi yanaşması veya bağlanması için yapılan tekil yapılarıdır. Şekil 1'de kıyı yanaşma yapılarının zemin ile olan etkileşimleri ifade edilmeye çalışılmıştır.

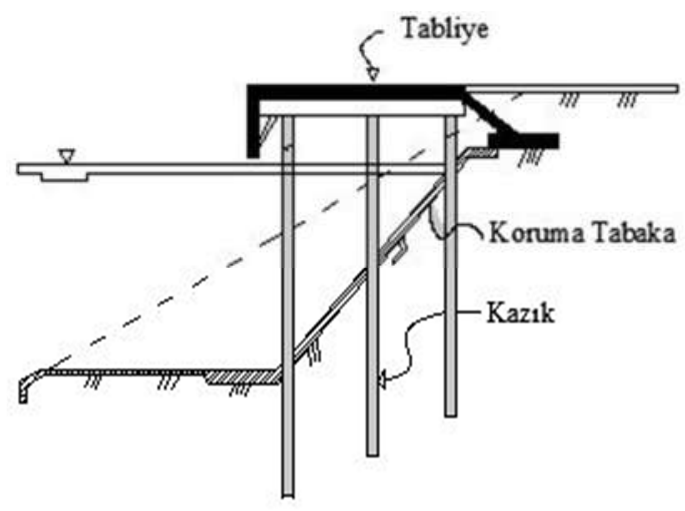

a) Açık tip rıhtım yanaşma yapısı

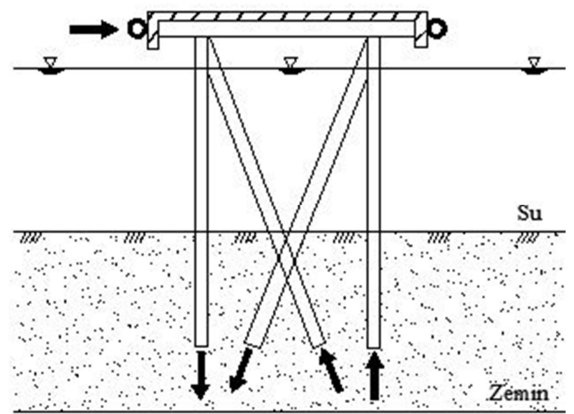

b) Açık tip iskele yanaşma yapısı

Şekil 1. Kıyı yanaşma yapıları [2]

Kıyı yanaşma yapılarına etkiyen rüzgâr, dalga ve deprem kuvvetleri tasarımlarda dinamik olarak değerlendirilir iken, gemi ve bağlama yükleri statik olarak dikkate alınabilmektedir. $\mathrm{Bu}$ kapsamda; kıyı yanaşma yapıları, üstyapıda meydana gelen düşey yükleri, dalga hareketinden dolayı ortaya çıkan dalga kuvvetlerini ve deniz araçlarının yanaşması sırasında ortaya çıkan yanaşma yüklerini güvenle zemine aktarabilecek şekilde kazıklı temeller üzerine oturtulurlar.

Zeminlerin taşıma gücü ve oturma yeterliliğinin artırılması açısından derin temeller önemli yap1 elemanlardır [3]. Derin temeller, statik ve dinamik koşullar altında yanal yüklenmeye maruz kalabilmektedirler. Özellikle liman ve kazıklı kıyı yanaşma yapılarında gemi çarpması, dayanma yapılarının temelleri, kule temelleri, rüzgâr ve dalga yükleri kazıkların yanal yüklenmesine birer örnektir. Ayrıca deprem gibi titreşim hareketlerinden ortaya çıkabilecek hasarların azaltılması ve önlenmesi açısından kazıklı temeller yapılara önemli katkılar sağlamaktır [3].

Yanal yüklerin etkisindeki kazıklarda yatay deplasmanlar meydana gelmektedir. Bu deplasmanlar sonucunda zeminde gerilmeler oluşmaktadır. Etki-tepki prensibine göre oluşa ndeplasman gerilme dağılımının belirlenmesinde p-y (kuvvet-deplasman) eğrileri kullanılır. Bu eğriler oluşturulurken zeminin elastik sınırlar içerisinde kaldığı kabul edilir ve p-y eğrileriyle zemin, elastik yaylara dönüştürülür [4]. Bu tür kazıklarda tasarım ölçütü, nihai taşıma gücüne ilave olarak kazıkların maksimum deplasmanıdır. 
Nihai taşıma gücü ve yer değiştirmelerin yanı sıra kazıkta eğilme ile göçme meydana gelme olasılığına karşı güvenlik gözetilmelidir. Bu şartlar altında kazıklardan beklenen ise, izin verilen yer değiştirme sınırları içinde kalarak yapının ömrü boyunca herhangi bir hasar veya göçme riski oluşturmamasıdır.

Kazıklar; yükleri iletme şekillerine göre sürtünme ve uç kazığı, imal edildikleri malzemeye göre; ahşap, betonarme, çelik, imalat şekline göre; çakma kazıklar, yerinde dökülen kazıklar olarak sinıflandırılırlar [5]. Kazık temeller, bir deprem sırasında temel hareketlerini azaltmanın en etkin yöntemlerinden biridir. Düşey servis yüklerinin tamamını ya da önemli bir kısmının kazığın etrafındaki çevre sürtünmesi ile taşınması durumunda sürtünme kazıkları, kazık uç direnci yolu ile taşınması durumunda uç kazıklar olarak çeşitlendirilmişlerdir.

Kazıklar genellikle grup şeklinde imal edilirler ve tek kazığın davranışından daha farklı bir yük deformasyon davranışı gösterirler. Grup kazık davranışına zemin ve kazık özelliklerinin yanında grubu oluşturan kazık sayısı, kazıkların yerleştirme biçimleri, kazıklar arası uzaklıklar ve kazık başlığının rijitliği ve zemin yüzeyi ile olan ilişkisi etkili olmaktadır. Şekil 2'de kazık çalışma prensibi gösterilerek, kazık çevresinde oluşan sürtünmeye bağlı kuvvetler ile uç kuvvetin birlikteliği formüle edilmiştir. Çalışmalarda kullanılan kazık tipine bağlı olarak dayanım katsayıları değişkenlik göstermektedir.

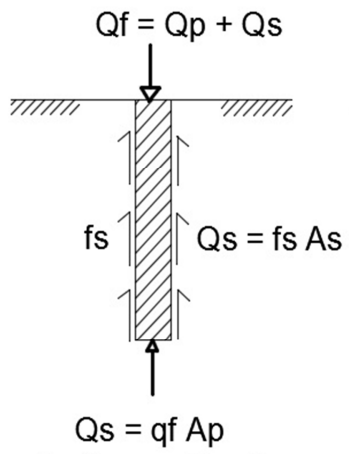

Sürtünme Kazığı

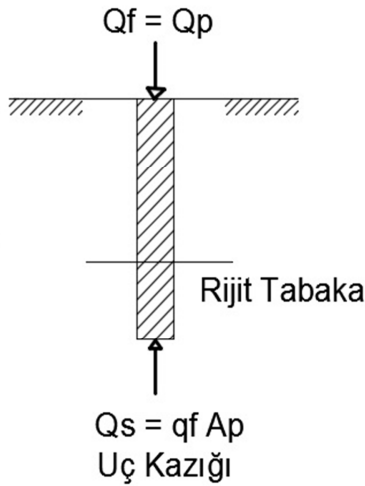

Uç Kazığı
Şekil 2. Kazık çalışma prensibi [6]
$Q_{f}$ : Tek kazığın nihai taşıma gücü,

$\mathrm{Q}_{\mathrm{p}}$ : Kazığın uç taşıma kapasitesi,

$\mathrm{Q}_{\mathrm{s}}$ : Kazığın sürtünme direnci,

$\mathrm{q}_{\mathrm{f}}$ : Kazık ucundaki zeminin birim nihai taşıma kapasitesi,

$\mathrm{f}_{\mathrm{s}}$ : Birim sürtünme direnci,

$A_{p}$ : Kazık ucundaki enkesit alanı,

$\mathrm{A}_{\mathrm{s}}$ : Kazık sürtünme alanı olarak ele alınır.

Son yıllarda gerçekleşen deprem ve tsunami felaketleri, dünya çapında kıyı ve liman yapılarının tasarımı konusunun önem kazanmasina sebep olmuştur. Ülkemizde ise, 2008 y1lında yürürlüğe giren Kıyı ve Liman Yapıları, Demiryolları, Hava Meydanları İnşaatlarına ilişkin Deprem Teknik Yönetmeliği (DLH 2008) kıyı ve liman yapılarının tasarım aşaması için önemli bir kılavuz olmuştur [7]. Yüksel ve Çevik [1] yayınladıkları kitaplarında liman yapılarının tasarımı ile ilgili geniş çaplı bilgiler sunmuşlardır. Yüksel ve Orhan [8], liman yapılarının sismik yüklemeler sonucunda oluşabilecek hasarlar konusunda bilgi vermişlerdir. Ülkemizde ilki 2013 ikincisi 2015 yılında düzenlenmiş olan Ulusal Liman Kongrelerinde liman ve yanaşma yapılarının çalışma kapasiteleri, verimlilikleri, yapılarda çeşitli sebeplerden oluşan hasarlar ve onarımları hakkında çalışmalar yürütülmüştür [9-10].

Kadıŏlu [11], İzmit körfezinde bulunan kazıklı rıhtım yapısını modellemiş ve doğrusal olmayan itme analizi gerçekleştirmiştir. Eğik çelik kazıkların eğim açıları değiştirerek modelin genel davranışına olan etkisini araştırmıştır. Düz ve eğimli kazıklı yapı arasında yer değiştirme talepleri yaklaşık 14 kat fark olmasına rağmen, eksenel kuvvette 1,5 ve eğilme momentinde 1,8 kat fark bulmuştur. Eğik ve düz kazıkların 3 boyutlu modelleri oluşturularak zaman tanım alanında doğrusal olmayan dinamik analizlerle zemin tipinin kazıkların davranışına etkisinin araştırılmasını önermiştir.

Topsoy [12], düşey kazıklı rıhtım yapısının taban kesme kuvvetlerinin de R katsayısı ile orantılı olarak değişiklik gösterdiğini gözlemlemiştir. Deprem yükleri kadar zemin yükleri, rüzgâr yüklerinin de kazık uç kuvvetlerine etkisinin olduğunu belirtmiştir. 


\section{MATERYAL VE METOT}

Daire kesitli çelik kazık üzerine oturan iskele yapılarının olası dalga yükleri altındaki davranışının incelendiği bu çalıșmada 6 adet sayısal model oluşturulmuştur. Sayısal modellerin belirlenmesi aşamasında kazık çapları ve bu çaplara bağlı olarak değişen kazık aralıkları parametre olarak kabul edilmiştir. DLH2008'de kazık aralıkları kazık çapına göre tanımlanmış olup, 3D-8D aralığında alınabileceği ifade edilmiştir [7]. Kazık çaplarına göre değer kazanan kazık aralıkları çalışma kapsamında $4 \mathrm{D}$ ve $8 \mathrm{D}$ olarak belirlenmiştir. Çalışmada kullanılan kazıkların çapları ve et kalınlıkları; D600x12 mm, $\mathrm{D} 800 \times 12 \mathrm{~mm}$ ve $\mathrm{D} 1000 \times 12 \mathrm{~mm}$ olarak belirlenmiştir. Kazık çapları üç değişken olarak belirlenirken cidar kalınlıkları 12 mm olarak kabul edilmiştir. Boru profillerin çelik malzeme sınıfı S275 seçilmiştir.
Şekil 3'de kazıkların plan yerleşimlerini belirleyen parametreler gösterilmiştir. Burada, L platform uzunluğunu, V platform genişliğini, L1 ve L2 $x$ doğrultusunda iki kazık arası mesafeyi, V1 ve V2 ise y doğrultusunda iki kazık arası mesafeyi ifade etmektedir. Kazık aralıkları, iskele temelinin plan yerleşimini belirlemektedir. Çizelge 2'de bu tanımlaya göre oluşturulan sayısal modellerin isimlendirmeleri ve boyutsal parametreleri ayrıntılı olarak sunulmuştur.

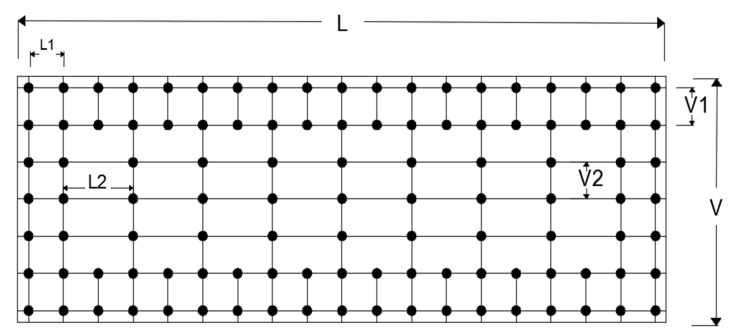

Şekil 3. Sayısal modellerde kullanılan kazıkların yerleşim planı

Çizelge 2. Sayısal modellerin boyutsal parametreleri

\begin{tabular}{|c|c|c|c|c|c|c|c|c|}
\hline $\begin{array}{c}\text { Model } \\
\text { No }\end{array}$ & $\begin{array}{c}\text { Kazık Çapı (D) } \\
(\mathbf{c m})\end{array}$ & $\begin{array}{c}\text { Kazık } \\
\text { Aralığı }\end{array}$ & $\mathbf{L}(\mathbf{m})$ & $\mathbf{L 1}(\mathbf{m})$ & $\mathbf{L 2}(\mathbf{m})$ & $\mathbf{V}(\mathbf{m})$ & V1 (m) & V2 (m) \\
\hline M1 & 60 & 4D & 59,60 & 2,40 & 4,80 & 21,20 & 2,40 & 4,80 \\
\hline M2 & 60 & 8D & 59,60 & 4,80 & 9,60 & 21,20 & 2,40 & 4,80 \\
\hline M3 & 80 & 4D & 59,60 & 3,20 & 6,40 & 21,20 & 3,20 & 3,20 \\
\hline M4 & 80 & 8D & 59,60 & 6,40 & 12,80 & 21,20 & 3,20 & 6,40 \\
\hline M5 & 100 & 4D & 58,00 & 4,00 & 8,00 & 22,00 & 4,00 & 4,00 \\
\hline M6 & 100 & 8D & 58,00 & 4,00 & 16,00 & 22,00 & 4,00 & 4,00 \\
\hline
\end{tabular}

Çizelge 2'de tanımlanan boyutsal parametreler kapsamında modellerdeki kazı sayıları değişkenlik göstermektedir. Bu kapsamda M1, M2, M3, M4, M5 ve M6 modelleri için sırasıyla $128,68,99,48,78$ ve 44 adet kazık kullanılmıştır. Kazıkları dört taraftan çevreleyen ve aralıklarda kazık başlıkları boşta kalmayacak şekilde $80 \mathrm{~cm}$ yüksekliğinde başlık kirişi ve $40 \mathrm{~cm}$ döşeme tanımlanarak üst yapı tamamlanmıştır. Modellerde kazık boyları sabit kabul edilmiş ancak deniz tabanındaki eğime göre zemine gömülü uzunlukları değişken olarak tanımlanmıştır. Daire kesitli boru profiller kullanılarak dizayn edilen kazıklı temel sistemine sahip modellere 8 metre dalga yüksekliği için 4 sn, 6 sn ve 12 sn dalga periyotları dikkate alınarak dalga kuvvetleri tanımlanmıştır. Boru profillere etkiyen dalga kuvveti Şekil 4'de gösterilmiştir [13].

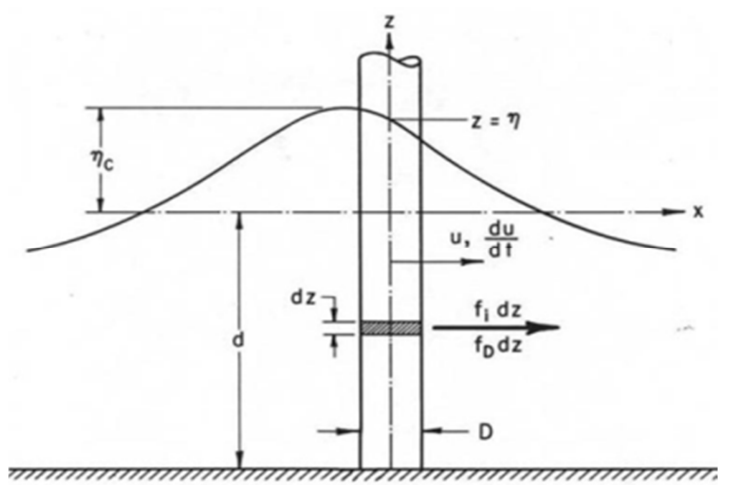

Şekil 4. Dairesel kesite etkiyen dalga kuvveti 
Dalga kuvvetlerinin hesaplanmasinda, Sap2000 sonlu elemanlar programı Eşitlik 1'de tanımlanan Morrison metoduna bağlı algoritma kullanmaktadır [14].

$\mathrm{F}=\mathrm{F}_{\mathrm{D}}+\mathrm{F}_{\mathrm{I}}=\mathrm{C}_{\mathrm{D}} \frac{\gamma_{\mathrm{su}}}{2} \mathrm{AU}|\mathrm{U}|+\mathrm{C}_{\mathrm{m}} \frac{\gamma_{\mathrm{su}}}{2} \mathrm{~V} \frac{\mathrm{dU}}{\mathrm{dt}}$

Burada F eleman boyuna eksenine birim uzunlukta etki eden hidrodinamik kuvveti, $F_{D}$ birim uzunluktaki sürükleme kuvvetini, $\mathrm{F}_{\mathrm{I}}$ birim uzunluktaki atalet kuvvetini, $\gamma_{\mathrm{su}}$ deniz suyunun birim hacim ağırlığını, A birim uzunluktaki alanı, V birim uzunluktaki hacmi, U elemanın eksenine normal etki eden su parçacık hızı bileşenini, $|\mathrm{U}| \mathrm{U}$ değerinin mutlak değerini, $\mathrm{dU} / \mathrm{dt}$ elemanın eksenine normal etki eden su parçacık ivmesi bileşenini, $C_{D}$ sürükleme katsayısını, $C_{m}$ atalet katsayısını ifade etmektedir $[14,15]$.

Sürükleme ve atalet katsayıları kazık geometrilerine göre değişkenlik göstermektedir. $\mathrm{Bu}$ çalışmada kullanılan dairesel kesitli kazıklar için sürükleme katsayısı $\left(C_{D}\right)$ ve atalet katsayısı $\left(C_{m}\right)$ değerleri sırasıyla 0,7 ve 2,0 olarak alınmıştır [15]. Deniz suyunun birim hacim ağırlığ ise $10,25 \mathrm{kN} / \mathrm{m}^{3}$ olarak programa tanımlanmıștır. Şekil 5'de dalga karakteristikleri gösterilmiştir.

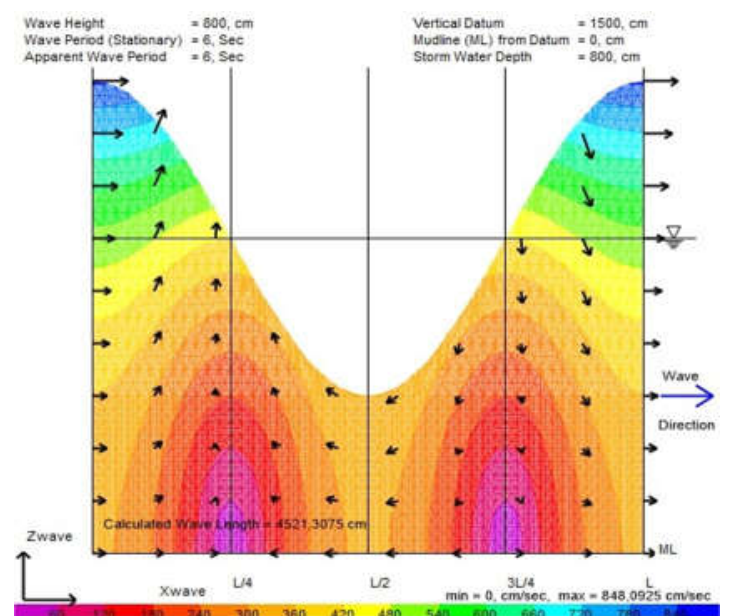

Şekil 5.Dalga karakteristikleri

Şekil 6'da çalışmada kullanılan sayısal modellerin kesit görünümleri verilmiştir. Kesitlerde deniz kotu, zemin eğimi ve bu eğime bağlı olarak farklı gömülü derinliğe sahip kazık sistemi gösterilmiştir. Ayrıca, analiz sonuçlarının değerlendirilmesi için veri okuması yapılan kazıklar kırmızı renk ile gösterilmiştir. Şekil 6'da gösterilen kazıkların seçiminde zemine gömülü uzunlukları ve yapı içindeki konumları dikkate alınmıştır.

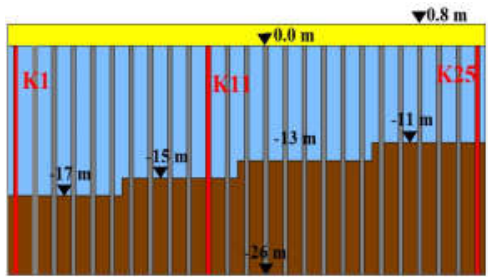

M1

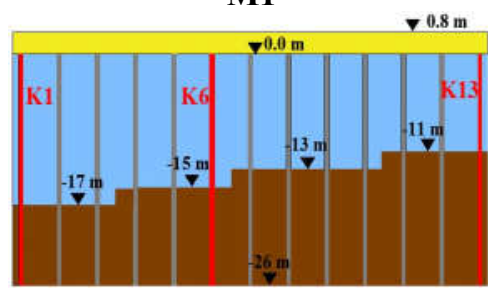

M2

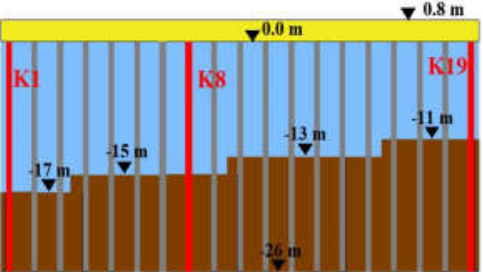

M3

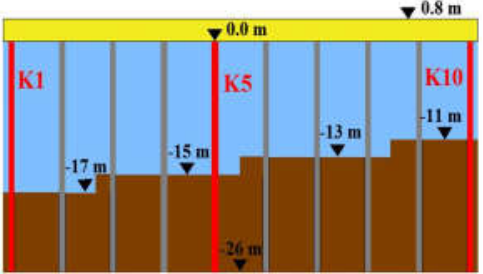

M4

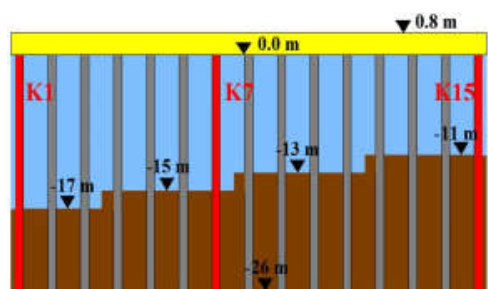

M5

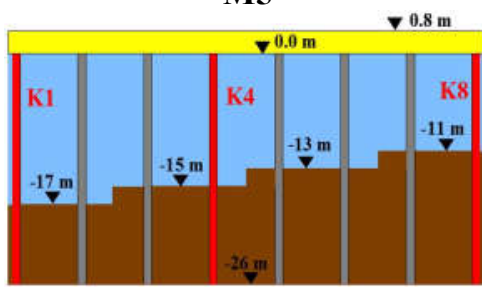

M6

Şekil 6. Sayısal modellerin kesit görünümleri ve analiz sonuçları için veri okuması yapılacak kazıkların belirlenmesi

Kesit ve plan yerleşim durumları ayrıntılı olarak tanımlanan iskele yapılarının $4 \mathrm{D}$ ve $8 \mathrm{D}$ yerleşim şekli için oluşturulmuş sayısal modellerinin 3 boyutlu görünümleri Şekil 7'de gösterilmiştir. 

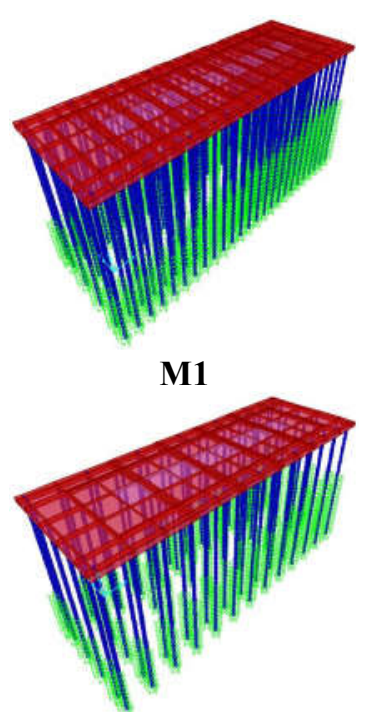

M2

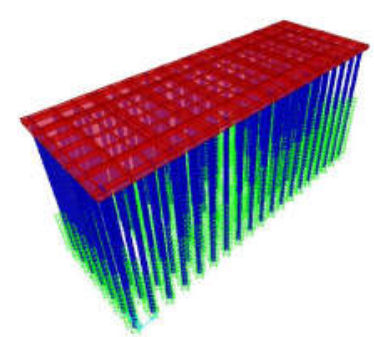

M3

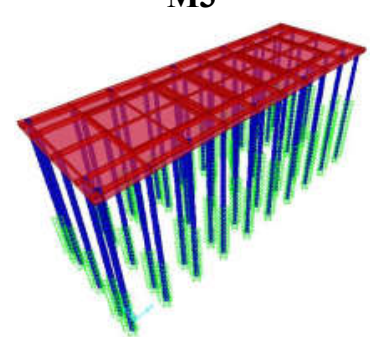

M4
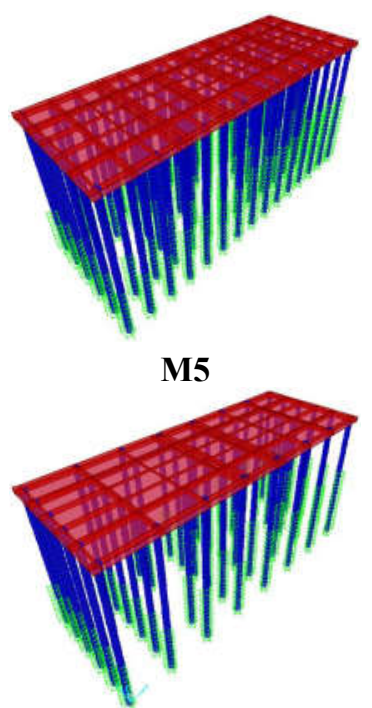

M6

Şekil 7. Kazık çapı ve aralığına göre yerleşim şekli değişen sayısal modellerin genel görünümleri

Kazık sisteminin oturduğu zemin tabakları katı kil üzerinde orta sıkılıkta kum olarak kabul edilmiştir. Tanımlanan zemin katmanı için 26 m yükseklikte olan tüm kazıklar orta sıkı kum içeresin de yer almaktadır. Şekil 8'de deniz tabanı zemin katmanları gösterilmiştir.

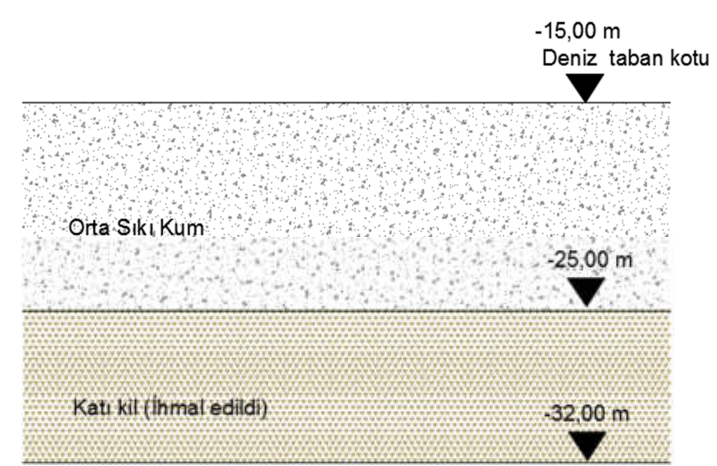

Şekil 8. Deniz tabanı için tanımlanan zemin durumu genel görünümü

Sayısal modellerde kazık zemin ilişkisi yay sabiti kullanılarak programa tanımlanmıştır. Yay sabitinin hesaplanmasında orta sıkı kum için kabul edilen kohezyonsuz zemine ait parametreler ile hesaplanan yatak katsayısı için kullanılan parametreler Çizelge 3 ve 4'de gösterilmiştir.
Çizelge 3. Kohezyonsuz zemin için tasarımda kullanilan parametreler [6]

\begin{tabular}{|c|c|c|c|c|}
\hline Zemin & $\begin{array}{c}\mathbf{E}_{\mathbf{s}} \\
\left(\mathbf{k N} / \mathbf{m}^{\mathbf{2}}\right)\end{array}$ & $\Phi$ & $\begin{array}{c}\mathbf{Y}_{\mathbf{d}} \\
\left(\mathbf{k N} / \mathbf{m}^{\mathbf{3}}\right)\end{array}$ & $\mathbf{V}$ \\
\hline Orta S1k1 Kum & 30000 & $35^{\circ}$ & 19 & 0,3 \\
\hline
\end{tabular}

$\mathrm{E}_{\mathrm{s}}$ : Elastisite modülü

$\Phi$ : Efektif kayma direnci açısı

$Y_{\mathrm{d}}$ : Zemin doygun birim hacim ağırlığı

$\mathrm{v}=$ Poisson oranın 1 ifade etmektedir.

Kumlarda yanal yatak katsayısı derinlikle doğrusal bir artış gösterir. $\mathrm{Bu}$ zeminlerde $\mathrm{Kh}$ (yatak katsayısı, $\mathrm{kN} / \mathrm{m}^{3}$ ) değeri Eşitlik 2 kullanılarak hesaplanmaktadır [6].

$\mathrm{Kh}=\mathrm{nh}^{*}(\mathrm{z} / \mathrm{B})$

Eşitlik 2'de ifade edilen nh, zemin sıkılığına bağlı katsayı, z derinlik (m), B kazık çapıdır (m).

Çizelge4. Kohezyonsuz zeminlerde nh değerleri [7]

\begin{tabular}{|c|c|c|}
\hline Zemin Sıkılı̆̆ & $\begin{array}{c}\text { YASS üzerinde } \\
\mathbf{n h}\left(\mathbf{k N} / \mathbf{m}^{\mathbf{3}}\right)\end{array}$ & $\begin{array}{c}\text { YASS altında } \\
\mathbf{n h}\left(\mathbf{k N} / \mathbf{m}^{\mathbf{3}}\right)\end{array}$ \\
\hline Gevşek & 2200 & 1300 \\
\hline Orta s1k1 & 6600 & 4400 \\
\hline Sık1 & 18000 & 11000 \\
\hline
\end{tabular}


Sayısal modellerde kazıkların gömülü derinlikleri 9-15 m aralığında değişmektedir. Sap2000 programında zemin yatak katsayısını temsil eden yay sabitleri birer metre için tanımlanmıştır [14]. Çizelge 5'de modellerde kazıkların her bir metre derinlik için tanımlanan yay sabiti değerleri derinlikçe gösterilmiştir. Sayısal modellerde, zemin içerisinde farklı derinliklerde çalıştığı ön görülen kazık sistemleri, Çizelge 5'de yatak katsayısı olarak tanımlanan yay sabitleri kullanılarak X ve Y yönü olan yatay doğrultularda sınır koşulları tanımlanmıştır.

Çizelge 5. Yatak katsayısı değerleri

\begin{tabular}{|c|c|c|c|}
\hline \multirow{2}{*}{$\begin{array}{c}\text { Derinlik } \\
(\mathbf{m})\end{array}$} & \multicolumn{3}{|c|}{ Yatak Katsayısı (kN/m $\mathbf{m}^{\mathbf{3}}$} \\
\cline { 2 - 4 } & $\mathbf{D 6 0}$ & $\mathbf{D 8 0}$ & $\mathbf{D 1 0 0}$ \\
\hline 1 & 7333 & 5500 & 4400 \\
\hline 2 & 14666 & 11000 & 8800 \\
\hline 3 & 22000 & 16500 & 13200 \\
\hline 4 & 29333 & 22000 & 17600 \\
\hline 5 & 36666 & 27500 & 22000 \\
\hline 6 & 44000 & 33000 & 26400 \\
\hline 7 & 51333 & 38500 & 30800 \\
\hline 8 & 58666 & 44000 & 35200 \\
\hline 9 & 66000 & 49500 & 39600 \\
\hline 10 & 73333 & 55000 & 44000 \\
\hline 11 & 80666 & 60500 & 48400 \\
\hline 12 & 88000 & 66000 & 52800 \\
\hline 13 & 95333 & 71500 & 57200 \\
\hline 14 & 102666 & 77000 & 61600 \\
\hline 15 & 110000 & 82500 & 66000 \\
\hline
\end{tabular}

\section{BULGULAR ve TARTIŞMA}

Bu çalışmada; altı adet sayısal modelin 4 sn, 6 sn ve 12 sn dalga periyodu etkisi altındaki davranışı analiz edilmiştir. Analiz sonuçlarında, kazıkların tabandan iskele platformuna kadar olan yüksekliği boyunca yatay yer değiştirmeler hesaplanmıştır.
Elde edilen değerler $60 \mathrm{~cm}, 80 \mathrm{~cm}$ ve $100 \mathrm{~cm}$ kazık çapı için 4D ve $8 \mathrm{D}$ yerleşim düzeninde karşılaştırılarak grafik halinde sunulmuştur.

Şekil6 üzerinde kırmızı renkle işaretlenmiş kazıklar için sistem içinde birbiri ile olan yatay yer değiştirme değerleri ve aynı kazıkların farklı dalga periyotları altındaki davranışları karşılaştırmalı olarak bu bölümde sunulmuştur. Bu kapsamda ilk olarak $60 \mathrm{~cm}$ kazık çap1 4D ve 8D yerleşim şekline ait M1 ve M2 nolu modeller kazık sistemleri yatay yer değiştirme değerleri Şekil 9'da verilmiştir. M1 ve M2 nolu modele ait sonuçlar incelendiğinde; kazıkların sistem içindeki davranışı tüm analizlerde, kazık üst kotlarının birlikte hareket ettiği yani iskele üst yapısının diyafram özelliği sergilediği görülmektedir. $\mathrm{Bu}$ durum tüm kazıkların sistem içerinde bir bütün çalıştığını göstermektedir. Kazıkların sistem içindeki durumlarını ifade eden Şekil 9.a'da, kazık aralığının azalması ve buna bağlı kazık sayısındaki artış, yatay yer değiştirme talebine etkin bir şekilde yansımış, $T=4$ sn, 6 sn ve 12 sn periyot değerlerine ait tüm yüklemelerde yatay yer değiştirmeler azalmıştır. Periyot değerlerinin kendi içindeki durumları değerlendirildiğinde, en kritik yatay yer değiştirme taleplerinin 4 sn'lik periyodu takiben 6 sn ve 12 sn periyotlarında oluştuğu görülmektedir (Şekil 9.b). Bu noktada dinamik bir yük olan dalga yükünün yüksek frekans düşük periyot değerinde yani tekrarlı yükleme altında daha yüksek yatay yer değiştirme talebinin olduğu görülmektedir.

Grafiklerde kesikli çizgiler ile tanımlanan sınırlar her kazığın deniz tabanına ulaştığı derinliği, yani gömülü kısmın başladığı kotu temsil etmektedir. Çalışmada kullanılan kazık boyları 26 m olarak tasarlanmıştır. Bu kapsamda yeşil renk ile ifade edilen kıyıya en yakın ve en çok gömülü derinliğe sahip olan kazık olup $15 \mathrm{~m}$ gömülü derinliğe sahiptir. Kırmızı renkle tanımlanan ve sistem kesitinde yap1 ortasında yer alan kazık olup gömülü derinliği 11 m'dir. Grafiklerde mavi renkle tanımlanan ve deniz tarafinda en uçta yer alan buna bağlı olarak en az gömülü derinliğe sahip olan kazık elemandır. Yapı ucundaki bu elemanın 
gömülü derinliği 9 m'dir. $\mathrm{Bu}$ kapsamda yapı içerindeki konumları ve gömülü derinlikleri değişen kazıkların yatay yer değiştirmelerinin sistem içindeki durumları incelendiğinde; en rijit davranışın beklendiği üzere kıyıya en yakın ve gömülü derinliği en çok olan kazıktan en aza doğru değiştiğidir.
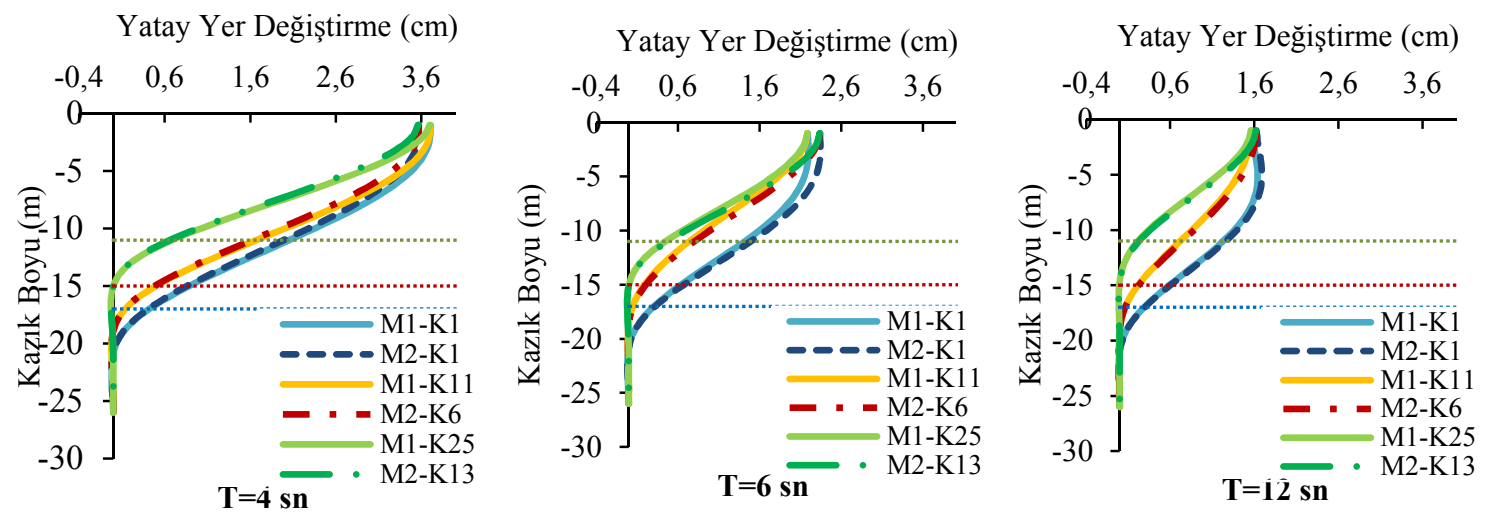

a) Sabit dalga periyodu altında farklı kazıklarda gerçekleşen yatay yer değiştirmeler

Yatay Yer Değiştirme (cm)

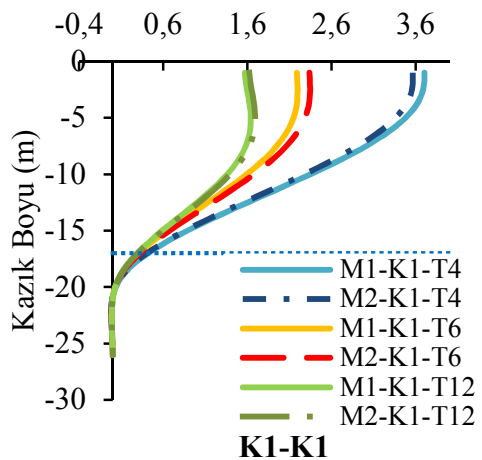

Yatay Yer Değiştirme (cm)

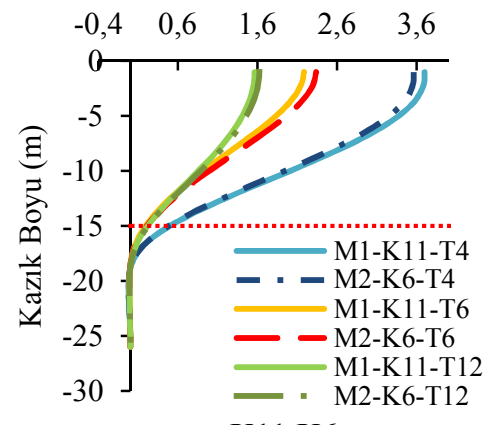

K11-K6
Yatay Yer Değiştirme $(\mathrm{cm})$

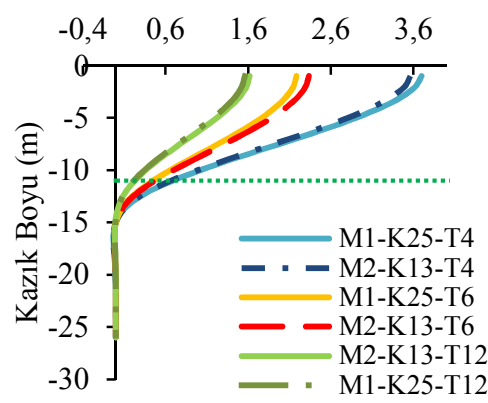

K25-K13

b) Değişken dalga periyotları altında kazıklarda gerçekleşen yatay yer değiştirmeler

Şekil 9. M1 ve M2 (D60 4D-8D) modellerinin dalga periyotlarına göre yatay yer değiştirme değerlerinin karşılaştırılması

Şekil 9.b'de yer alan grafiklerde seçilen her bir kazığa farklı periyotlarda etkiyen dalga yüklerinin $4 \mathrm{D}$ ve $8 \mathrm{D}$ yerleşim düzeni için kazıkların kendi içindeki kıyaslamalarını içermektedir. Bu durum değerlendirildiğinde; en çarpıcı tespitin gömülü derinliğin deniz tabanını temsil eden sınır çizgisi dikkate alındığında tüm kazıklarda ortalama 3-5 m aralığında değişen derinlikte zeminin yatay yer değiştirmeyi tutamadığı, başka bir ifade ile kazık elemanın mesnet etkisinin sınır çizginin en az $5 \mathrm{~m}$ altında başladığıdır. Orta aksta ve kıyıya yakın uçtaki konumda yer alan kazıklarda bu sınırın altında zeminden kazanılan rijitlik etkiyen yüke cevap verebilecek rijitlikte kalırken, denize yakın uçtaki kazık sistemi için yeterli rijitlik sağlayamamaktadır.

Şekil 10'da M3 ve M4 nolu modellerin yani $80 \mathrm{~cm}$ çapındaki kazık sisteminin 4D ve 8D yerleşim düzenindeki sayısal modellere ait analiz sonuçlarından elde edilen yatay yer değiştirme karşılaştırmaları yer almaktadır. 

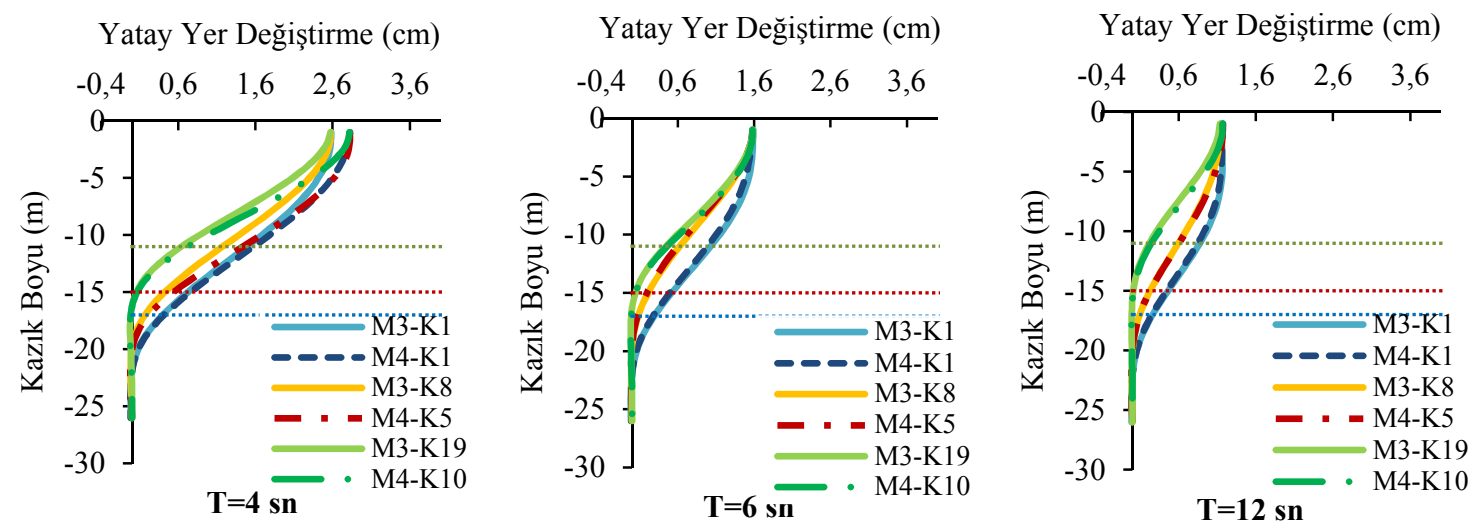

a) Sabit dalga periyodu altında farklı kazıklarda gerçekleşen yatay yer değiştirmeler

Yatay Yer Değiştirme $(\mathrm{cm})$

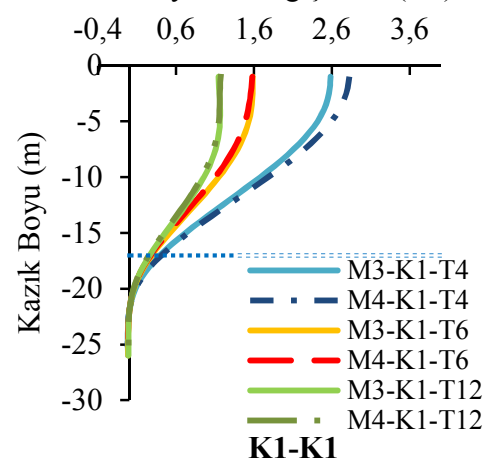

Yatay Yer Değiştirme $(\mathrm{cm})$

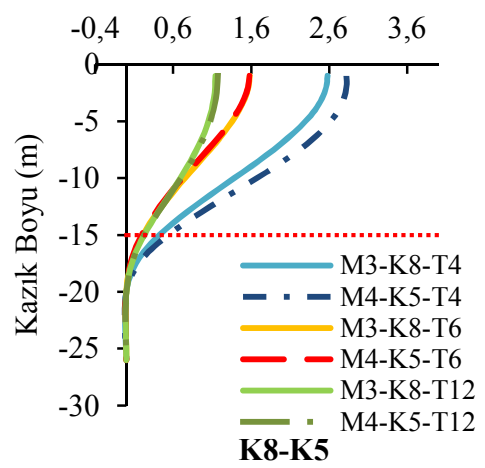

Yatay Yer Değiştirme (cm)

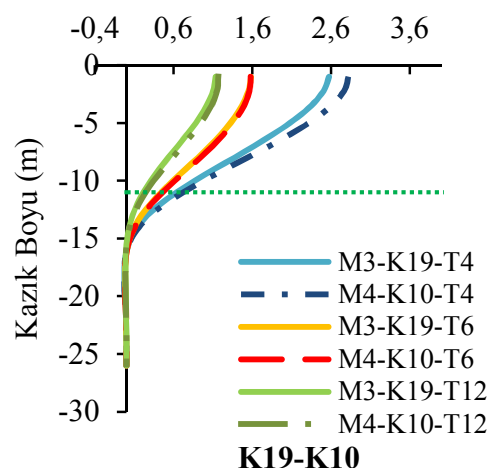

K19-K10

b) Değişken dalga periyotları altında kazıklarda gerçekleşen yatay yer değiştirmeler

Şekil 10. M3 ve M4 (D80 4D-8D) modellerinin dalga periyotlarına göre yatay yer değiştirme değerlerinin karşılaştırılması

$80 \mathrm{~cm}$ çaplı kazıkların sistem içindeki durumlarını temsil eden grafikler incelendiğinde, elde edilen yatay yer değiştirme eğrilerin $60 \mathrm{~cm}$ çapındaki sayısal modellere göre daha rijit bir davranış sergilediği görülmektedir. Bu sayısal modellerde de, 4D yerleşimin sistem yatay yer değiştirme talebini azaltmış olduğu görülmektedir. Bu kazık çapı için yerleşimden kazanılan rijitlik artışı $60 \mathrm{~cm}$ 'lik sisteme göre daha belirgin bir hal almış, 4D sonucundaki yatay yer değiştirme değerleri 8D aralığında yatay yer değiştirme değerlerinin \%60 oranında azalmasına sebep olmuştur. Yerleşim düzeninin kazık çapına göre şekil aldığı sayısal modellerde, kazık çapına bağlı olarak aralık ve kazık sayısı değişkenlik göstermektedir. $\mathrm{Bu}$ kapsamda kazık aralığın artması ve kazık sayısının
M1 ve M2 nolu modellere göre azalmasına rağmen kazık çapındaki artış, daha etkin sonuç vermiştir.

Şekil 10'da seçilen kazık elemanlarının kendi içlerindeki durumlarını ifade eden grafikler incelendiğinde; her kazık için zemin sınır çizgisi davranış karşılaştırmasının $60 \mathrm{~cm}$ 'lik modellere göre daha rijit kaldığı burada da görülmektedir. Bu modellerde sınır çizgisi altındaki zeminin etkin mesnet tepkilerinin oluşamadığı, başka ifade ile gelen yüklere karşılık veremediği mesafe 3 m'ye düşmüştür. Ayrıca $80 \mathrm{~cm}$ 'lik modellerde denize en yakın uçta yer alan kazık dâhil olmak üzere tüm kazıklar etkin çalışma derinliğinin altında yeterli rijitliğe ulaşmıştır. 
Calıșma kapsamında son modeller olan $100 \mathrm{~cm}$ kazık çapının 4D ve 8D yerleşim planındaki M5 ve
M6 nolu modeller için elde edilen sayısal analiz sonuçları Şekil 11'de karşılaştırılmıştır.
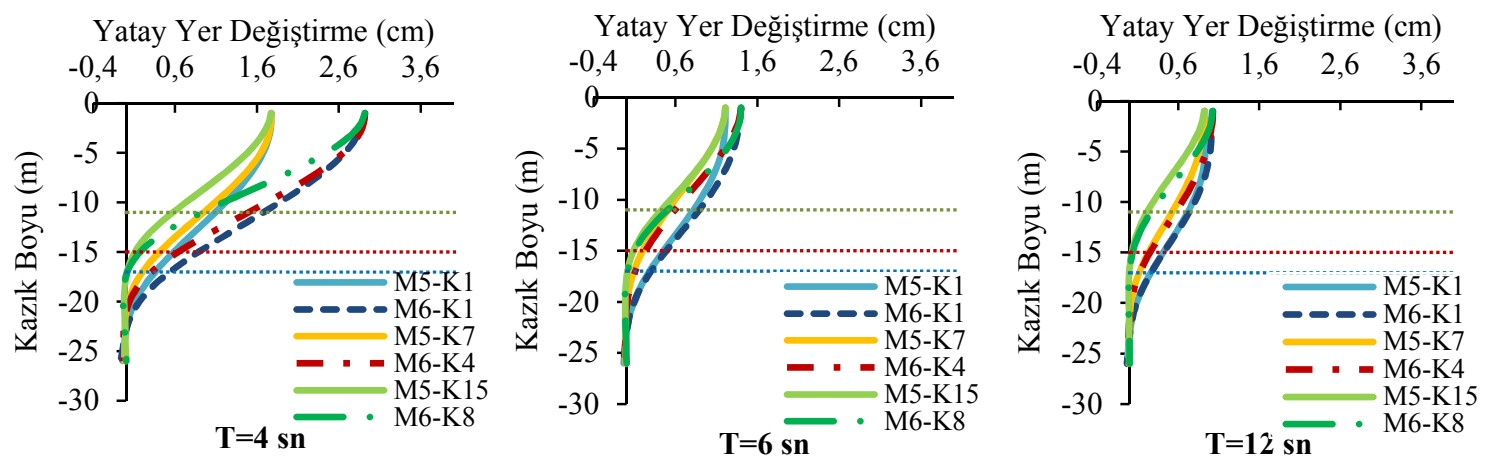

a) Sabit dalga periyodu altında farklı kazıklarda gerçekleşen yatay yer değiştirmeler
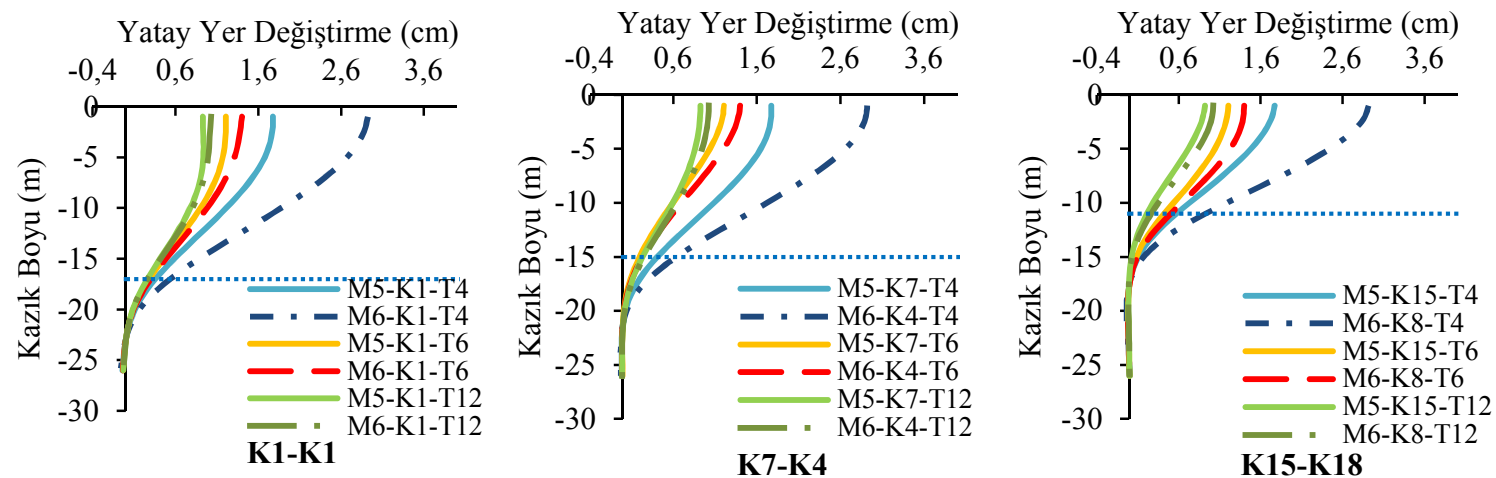

b) Değișken dalga periyotları altında kazıklarda gerçekleşen yatay yer değiștirmeler

Şekil 11. M5 ve M6 (D100 4D-8D) modellerinin dalga periyotlarına göre yatay yer değiştirme değerlerinin karşılaştırılması

100 cm'lik kazıkların sistem içindeki kıyaslamalarına baktığımızda, bu yerleşim düzeninde kazık platform kotu tepe yer değiştirmesi açısından 4D yerleşim düzeni için 8D'ye göre elde edilen kazanım, diğer modellere göre daha belirgin durumdadır.

M5 ve M6 nolu modeller kazık sisteminin kendi içinde karşılaştırması dikkate alındığında ise diğer modellerden farklı olarak; $\mathrm{Bu}$ sistemde deniz kenarına yakın kısımdaki uçkazıkta, kazık ucunda da deplasman tespit edilmiştir. Başka bir ifade ile bu modellerde, en uçtaki kazık sahip olduğu gömülü derinlik, kazığa etkiyen yükleri sönümleyecek düzeye ulaşamamıştır. Ancak kazık sisteminin üst tablada diyafram olarak çalışıyor olması sayesinde, bu kazıktaki yetersizlik diğer sistem elemanlarınca karşılanmıştır. Diyafram etkisi ile elde edilen bu kazanım dinamik bir yük olan dalga yükünün, iskele yapısı için tekrar aralığı dikkate alındığı hizmet ömrü açısından değerlendirilmelidir.

Değişen dalga periyodu (4 sn, 6 sn ve 12 sn) sabit dalga yüksekliği $(8 \mathrm{~m})$ için sayısal modellerin yatay yer değiştirme taleplerinin taşıma kapasitesi açısından değerlendirilebilmesi için; en etkin dalga kuvveti altında tüm modellerde dikkate alınan kazık elemanların kesme kuvveti ve moment dağılım grafikleri elde edilmiştir. Kapasite grafiklerinin sistem güvenliği açısından değerlendirilebilmesi için Çizelge 6'da kullanılan 
kazık çaplarının sistem içerindeki yük durumları da dikkate alınarak kesme kuvveti ve moment taşıma kapasiteleri lineer sınır için belirlenmiş ve Çizelge 6 üzerinde gösterilmiştir.

Çizelge 6. Kazıkların çaplarına bağlı kesme kuvveti ve moment kapasite değerleri

\begin{tabular}{|c|c|c|}
\hline $\begin{array}{c}\text { Kazık Çapı (D) } \\
\text { (cm) }\end{array}$ & $\begin{array}{c}\text { Kesme Kuvveti } \\
\text { (kN) }\end{array}$ & $\begin{array}{c}\text { Moment } \\
\text { (kN/m) }\end{array}$ \\
\hline 60 & 196 & 1650 \\
\hline 80 & 275 & 1890 \\
\hline 100 & 425 & 2350 \\
\hline
\end{tabular}

Yapılan çalışmada, kazık sistemi üst yapıyla birlikte analiz edilmiştir. Bu durum kazık başının üst yapı kütle eylemsizliğinden etkilenerek rijitlik kazanmasına sebep olmuştur. Üst yapı kazık etkileşiminden kazanılan bu rijitlik kazık elastik eğrisini de belirlemiştir. Çalışmada kullanılan tüm kazıklar orta sıkı kum içerisinde değerlendirildiği için tamamı sürtünme kazığı olup kazık ucunda soketlenme ihmal edilmiştir. $\mathrm{Bu}$ durumun

Kesme Kuvveti (kN)

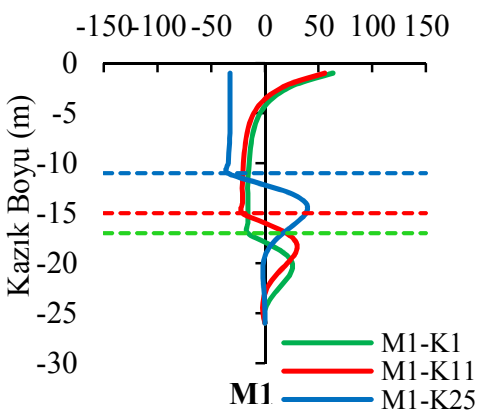

Kesme Kuvveti $(\mathrm{kN})$ $-150-100-50 \quad 0 \quad 50 \quad 100150$

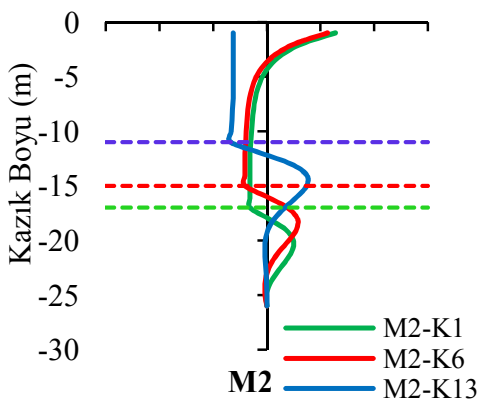

matematik modellenmesi ve buna bağlı elastik şekil değiştirmesi Şekil 12'de gösterilmiştir.

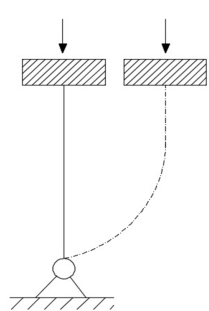

a)

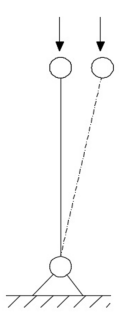

b)
Şekil 12. Kazık davranışının gösterimi. a) Kazık üstünde platform olması durumu, b) Kazık başının boş olması durumu

Çalışma kapsamında dikkate alınan modellere ait olan kazık kesme kuvveti ve moment değerleri ölü yük, hareketli yük ve dalga periyotları içinde en etkili durum olan 4 sn periyot için kombinasyon oluşturularak okumalar yapılmış ve elde edilen grafikler Şekil 13, 14 ve 15'de gösterilmiştir.

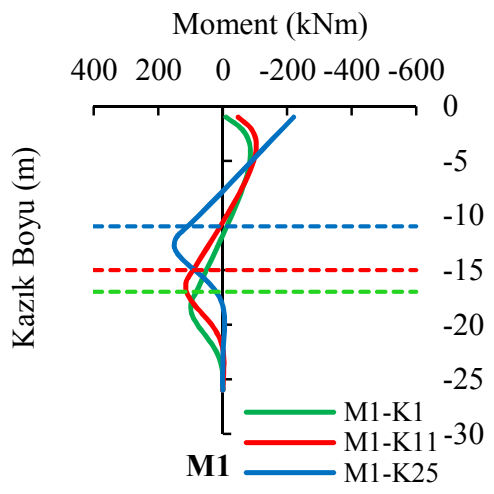

Moment $(\mathrm{kNm})$

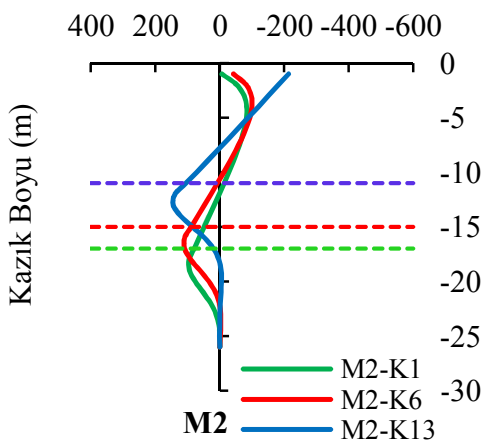

Şekil 13. M1 ve M2 nolu modellerin 4 sn dalga periyodu için kesme kuvveti ve moment dağılımlılarının karşılaştırılması 
Kazık çapının $60 \mathrm{~cm}$ olduğu modellere ait grafikler incelendiğinde, bu dalga periyodu için elde edilen tüm değerlerin kazık kapasite değerini aşmadığ tüm kazıkların lineer sınırlar dâhilinde kaldığı görülmektedir. Kesme kuvveti ve Moment değerlerinin kazık boyunca dağılımının verildiği grafikler incelendiğinde; elde edilen verilerin yatay yer değiştirme davranış1 ile örtüştüğü görülmektedir. Bu grafiklerde kesme kuvveti için sönüm sınır çizgisi ile başlasa da, etkinin tamamı ile sönümü için gömülü derinliğin tamamı kullanılmaktadır.

M2 (D60-8D) modelinde, kesme kuvvetleri dağılımları K1-K6 kazıkları için pozitif bölgede başlamış, devam eden durumda K13'de olduğu gibi negatif bölgeye geçiş ve dağıllımca kendi içlerinde paralellik göstermiştir. K1-K6 kazıklarının etkiyen dalga kuvveti için dalga pik noktalarına karșılaşması sebebi ile K13'ten başlangıç itibari ile ayrıșmıștır. Moment değerlerinin kazık boyunca dağılımları incelendiğinde, en belirgin durumun, çalışmada kullanılan matematik modelin bir sonucu olarak, kazık başlarının moment almasıdır. Bu durumda kazık başı moment değerleri incelendiğinde, zemin gömülü derinliği en yüksek olan ve kuvvet doğrultusu dikkate alındığında üst yapı ile etkileşimi en yüksek olan K6, K13 kazıkları için hesaplanan uç momentleridir. Bu noktada sahip olduğu rijitliğin üst yapıdan elde edilen eylemsizliğe bağlı momentin ilişkili olduğu söylenebilir.

Kazık çapının $80 \mathrm{~cm}$ olduğu modellere ait grafikler incelendiğinde, dalga pik noktalarına bağlı oluşan kesme kuvveti değerleri bu modelde de açikça görülmektedir (Şekil 14).
Kesme Kuvveti (kN)

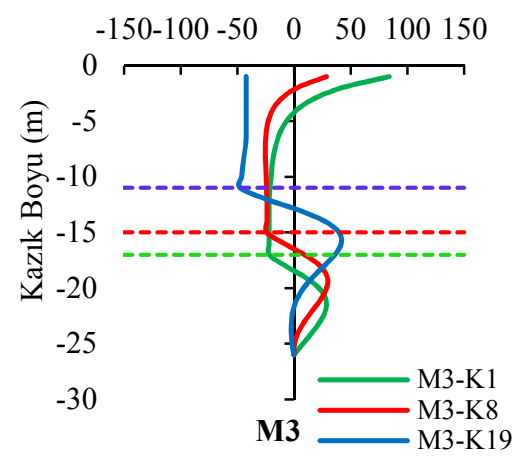

Kesme Kuvveti (kN)

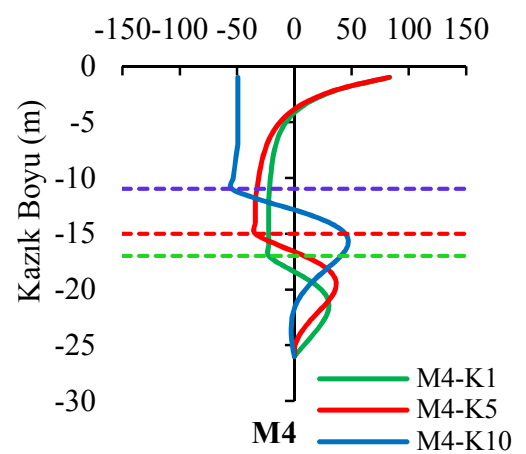

Moment (kNm)

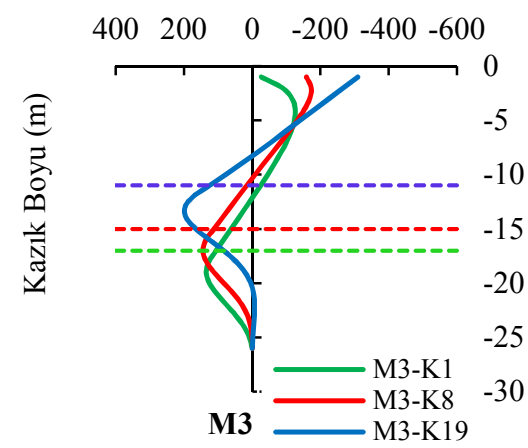

Moment (kNm)

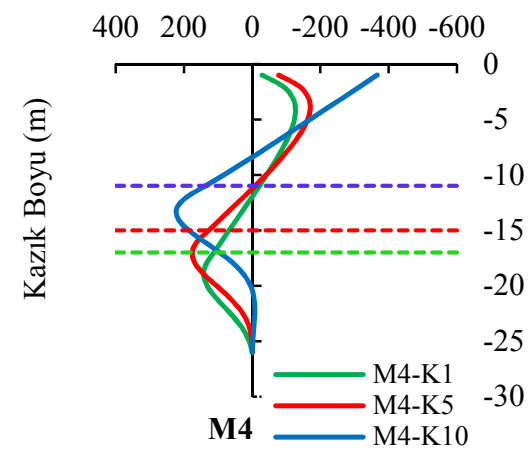

Şekil 14. M3 ve M4 nolu modellerin 4sn dalga periyodu için kesme kuvveti ve moment dağıllımlılarının karşılaştırılması 
$80 \mathrm{~cm}$ kazık çapı için elde edilen tüm kesme kuvveti diyagramlarında, kesme kuvveti değerlerinin tümüyle zemin tarafından karşılandığ görülmektedir. Moment dağılımını ifade eden grafikler incelendiğinde $4 \mathrm{D}$ ve $8 \mathrm{D}$ plan yerleşim düzeni için elde edilen kazık çapının büyümesine

Kesme Kuvveti (kN)

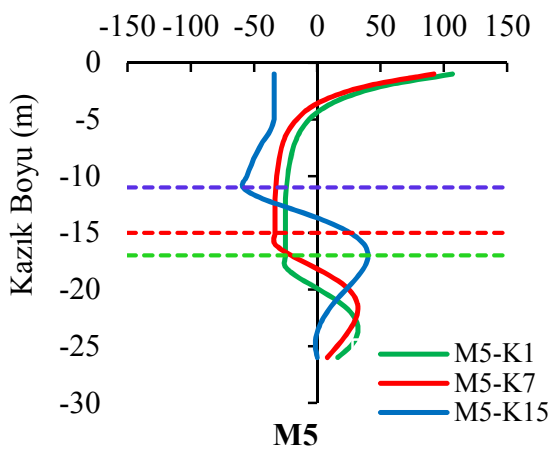

Kesme Kuvveti $(\mathrm{kN})$

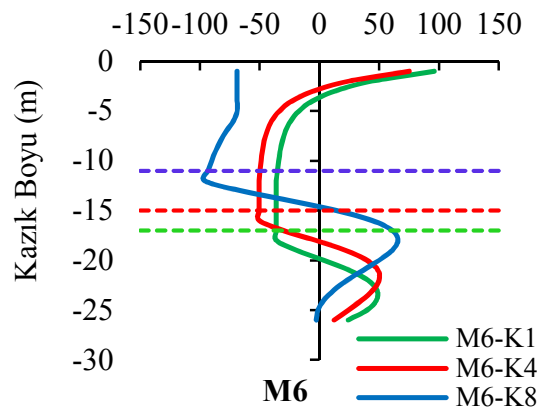

bağlı rijitlik kazanımı kazık uç momentinin artışına sebep olmuştur. Bu durum bir önceki kazık çapındaki kazık rijitliği ile üst yapı etkileşimindeki pozitif yaklaşımının bir teyidi niteliğindedir. $\mathrm{Bu}$ kapsamda elde edilen uç momentler, $60 \mathrm{~cm}$ kazık çapının büyük olduğu açıkça görülmektedir.
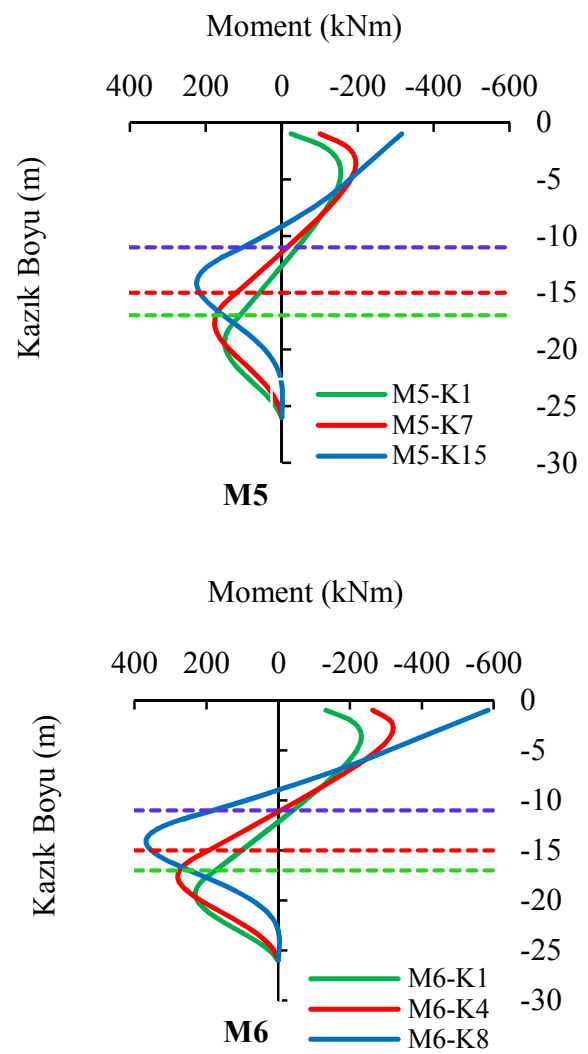

Şekil 15. M5 ve M6 nolu modellerin 4 sn dalga periyodu için kesme kuvveti ve moment dağılımlılarının karşılaştırılması

Kazık çapının $100 \mathrm{~cm}$ olduğu modellere ait sonuçlar incelendiğinde; bu modellerde kazık çapının en büyük boyutta olmasına karşın, kazık çap1 ile doğru orantılı olarak büyüyen kazık aralığ kazık zemin etkileşimden kazanılan rijitliği etkilemiştir. $\mathrm{Bu}$ kapsamda hem kesme kuvvetlerinin hem de moment kuvvetlerinin sönümlenmesi diğer modellere göre kıyasla daha geniş aralıkta gerçekleşmiştir. Ayrıca kesme kuvveti değerleri 8D yerleşim planındaki modelde tamamı ile sönümlenememiş, sistem taban kotunda artık kuvvet kalmıştır.

$\mathrm{Bu}$ kuvvet nedeniyle Şekil 11'de kazığın taban kotunda yatay yer değiștirme yapması olarak sonuç vermiştir. $100 \mathrm{~cm}$ kazık çapı için elde edilen moment diyagramları incelendiğinde kazık uç momentlerinin diğer kazık çaplarına göre daha da arttığı açıçca görülmektedir. $\mathrm{Bu}$ durum kazık rijitliğinin üst yapı etkileşimindeki pozitif kazanıma destek vermektedir. $100 \mathrm{~cm}$ kazıklarda diğer modellerden 4D-8D karşılaştırması noktasında kazık uç moment değerleri ayrışmıștır. $\mathrm{Bu}$ durum kazık grup etkisinin kazık sayısının 
enaz olduğu bu modelde, kazık bireysel rijitliklerinin ön plana çıkmasıdır.

\section{SONUÇLAR}

Dalga periyotlarındaki değişimin iskele yapısı kazık sistemi üzerine etkisinin incelendiği bu çalışmada; 4 sn, 6 sn ve 12 sn dalga periyodu, $8 \mathrm{~m}$ dalga yüksekliği için analiz edilmiştir. Analizlerde hesaplanan dalga yükleri kazık çapına göre kazık yerleşimin değiştiği altı adet sayısal model üzerinde değerlendirilmiştir.

Analizlerde kazık çapı $60 \mathrm{~cm}, 80 \mathrm{~cm}$ ve $100 \mathrm{~cm}$ olarak alınmıştır. Bu kazık çapları için kazık aralıkları $4 \mathrm{D}$ ve $8 \mathrm{D}$ yerleşim düzeninde sayısal model sayısı artırılmıştır. Tüm modellerde zemin parametreleri ve kazık uzunlukları sabit alınmıştır. Sap2000 sonlu elemanlar programı kullanılarak kazıkların yatay yer değiştirmeleri ve bu yer değiştirmeyi tetikleyen kesme kuvveti ve moment diyagramları elde edilmiştir. Elde edilen veriler karşılaştırmalı olarak sunulmuştur.

Dalga yüksekliği sabit tutularak değişen dalga periyodu için yapılan analizlerde dalga periyodundaki azalma (frekanstaki artış), kazıkların yatay yer değiştirmelerinde artış olarak sonuç vermiştir. Yapılan incelemede; bu durum dalganın pik noktalarının kazık kesiti teması ile ilgili olmayıp, dalga periyodunun yapı periyoduna yakınlaşması ile ilişskili olduğu sonucuna varılmıştır.

Yatay yer değiştirme grafiklerinde kazık aralıklarının etkiyen dalga kuvveti içindeki durumları dikkate alındığında, kazık çapı ve bu çap için kullanılan aralıklı yerleşim düzeninin, 4D ve 8D kıyaslamalarında, kazık aralığındaki düşüşe bağlı rijitlik kazanımı en etkin $80 \mathrm{~cm}$ kazık çapı için elde edilmiştir.

Çalışmada tanımlanan iskele modellerinde kullanılan kazık yapısı dikkate alındığında; kazık performansı, kazık çapı ve kazığın içindeki zemin ile olan etkileşiminin bir sonucu olarak davranış sergilemektedir. Çalışmada bu durumu ifade etmek için kazıkların kendi içlerindeki davranışları deplasman grafiklerine yansıtılmıştır. Grafiklerden elde edilen sonuca $100 \mathrm{~cm}$ kazık çapı 8D'lik yer değiştirmelerine ait grafiklerde gömülü derinliği 9 m olan kazık elemanın kazık taban kotunda yatay yer değiştirmenin sınırlanamadığı, kazığın bütüncül olarak hareket ettiği tespit edilmiştir. Aynı modelin $11 \mathrm{~m}$ ve $15 \mathrm{~m}$ gömülü kazık boyuna sahip sonuçlarında ise gömülü sınır çizgisinin ancak 4-5 m altında sönümlenme gerçekleşmiştir. $60 \mathrm{~cm}$ ve $80 \mathrm{~cm}$ çaplı tüm modellerde yatay yer değiştirmenin zemin içinde gömülü sınır çizgisinin ortalama 3-5 m altında tamamı ile sönümlendiği görülmüştür.

Kazıkların etkiyen dalga yükü atındaki karşılaştığ maksimum kesme kuvveti ve moment değerleri, kazık ortalama taşıma kapasiteleri ile lineer sınır dikkate alınarak karşılaştırılmıştır. Elde edilen veriler, hem kesme kuvveti hem moment için çalışmada tanımlanan periyot değerleri için lineer sınırı aşmamıştır. Davranışça durum değerlendirildiğinde; $60 \mathrm{~cm}$ ve $80 \mathrm{~cm}$ kazıklarda zemin yeterli sönüm rijitliği sağlamış, kazık moment sönümlemesi, kazık gömülü sınırın üzerinde başlamıştır. Kesme kuvveti değerleri ise bu modellerde gömülü sınır çizgisi altında 2-3 m aralıkta sönümlenmeye başlamış ve kazık taban kotunda tamamı ile sönümlenmiştir. $100 \mathrm{~cm}$ kazıkta ise kesme kuvveti değerleri taban kotunda sönümlenmemiş, artık kuvvet kalmıştır. Bu durum yatay yer değiştirme grafiği ile birlikte değerlendirildiğinde, yük değeri olarak lineer sınırın çok altında çalışmasına rağmen tekrarlı yüke maruz bu kazık için tehlike arz etmektedir. Ayrıca, kesme kuvveti diyagramlarında, dalga pik noktaları ile etkileşim içinde olan kazık elemanlarda pozitif kesme kuvveti ile başlamış, zemin etkisi devreye girdikçe, davranış ve dağılımca tüm kesme kuvvetleri aynı paralellikte sonuçlar vermiştir.

Çalışmada kazık ekseni moment dağılımı grafiklerinden elde edilen diğer önemli sonuç kazık başlarının moment almasıdır. Buradaki temel sebep, bu çalışmada kazık sistemi ve üst yap1 birlikte analiz edildiği için üst yapıdaki kütleye bağlı eylemsizlik kazık başında rijitlik sağlamaktadır. Eylemsizliğe bağlı elde edilen bu rijitlikte kazık başının moment almasına sebep vermektedir. Bu durum kazıklı temel sistemlerinin 
üst yap1 ile birlikte analiz edilmediği durumlarda kazık başının moment almadığı momentin kazık boyunca artarak gittiği şeklindedir. Ancak bu çalışmada elde edilen sonuç dikkate alındığında kazık başında hesaplanan kütle eylemsizliğine bağlı rijitlik tasarımcının gözardı edemeyeceği kadar büyük bir değer olduğudur. Kazık başındaki moment değerleri dikkate alındığında, kazık başı moment değerinin kazığın zemin ve kendi kesit özelliklerine bağlı rijitlik kazanımı ile direkt alakalı olduğudur. Bu noktada, en büyük moment değerleri, $80 \mathrm{~cm}$ ve $100 \mathrm{~cm}$ kazıklarda elde edilmiştir. Kazık rijitlik kazanımdaki artış üst yapı eylemsizlik kazanımına pozitif olarak yansımaktadır. $\mathrm{Bu}$ durumun kazığın üst yap1 içerisindeki konumu ile de ilişkili olduğu grafiklerde ayrıca tespit edilmiştir. $\mathrm{Bu}$ kapsamda en yüksek kazanım orta aks ve kıyı aksındaki kazıklarda elde edilmiştir. Orta akstaki kazanım üst yapı kaynaklı, kıyı aksındaki kazanım zemin etkisine bağlı kazık rijitliğindeki artış kaynaklı olduğudur.

Sonuç olarak; bu tipteki yapılarda dalga periyodundaki düşüş (frekanstaki artış), yatay yer değiştirme talebini de beraberinde getirmektedir. $\mathrm{Bu}$ tipteki sistemlerde kullanılacak kazık elemanlarında kazık çapına göre şekil alan kazık aralığında, özellikle 8D'lik yerleşim planlamasında, kazık yatay yer değiştirmeleri zemin koşulları için sorgulanmalıdır. $\mathrm{Bu}$ kapsamda, bu zemin koşulu için yapılan analiz sonuçlarınca kazık gömülü derinliği kazık boyunun en az \%40-45 olmalıdir.

\section{KAYNAKLAR}

1. Yüksel, Y., Çevik, E., 2006. Liman Mühendisliği, Beta Yayınevi (1. Baskı), 558, İstanbul.

2. Thoresen, C.A., 2004. Port Designer's Handbook: Recommendations and Guidelines. Thomas Telford, 549, London.

3. Kayadelen, C., Bağrıaçık, B., Altay, G., 2019 Kazıkların Deprem Etkisi Altında Íncelenmesi Çukurova Üniversitesi Müh Mim Fak. Dergisi, 34, 51-56.

4. Şahin, D., 2016. Kazıklı Kıyı Yanaşma Yapılarının Analiz ve Tasarım Aşamalarının
İncelenmesi. İstanbul Teknik Üniversitesi, Yüksek Lisans Tezi, 179, İstanbul.

5. Coduto, D.P., 2011. Temel Tasarımı: İlkeler ve Uygulamalar (2. Baski), Gazi Kitabevi, 816, Ankara.

6. Polat, Ş.Ş., 2008. Deformation Based Seismic Design of Pile Supported Marine Facilities, Boğaziçi Üniversitesi, Kandilli Rasathanesi ve Deprem Araştırmaları Enstitüsü, Doktora Tezi, 195, İstanbul.

7. DLH, 2008. T.C. Ulaştırma Bakanlığı, Kıyı ve Liman Yapıları, Demiryolları, Hava Meydanları İnşaatlarına İlişkin Deprem Teknik Yönetmeliği.

8. Yüksel, Y., Orhan, K., 2013. Sismik Risk ve Limanlarda Hasar Tipleri, 1. Ulusal Liman Kongresi, Dokuz Eylül Üniversitesi, İzmir.

9. 1. Ulusal Liman Kongresi, 2013. Dokuz Eylül Üniversitesi, İzmir.

10.2. Ulusal Liman Kongresi, 2015. Dokuz Eylül Üniversitesi, İzmir.

11. Kadıŏlu, Z., 2015. Kazıklı Kıyı Yapılarının Doğrusal Olmayan Davranışı ve Şekil Değiştirmeye Göre Tasarım, Gebze Teknik Üniversitesi, Yüksek Lisans Tezi, 83, Gebze.

12. Topsoy, E., 2016. Kıyı Yanaşma Yapılarının Tasarımı, Onarım ve Güçlendirilmesi, İstanbul Teknik Üniversitesi, Yüksek Lisans Tezi, 179, İstanbul.

13. CERC, 2003, Coastal Engineering Manual.

14. CSI, SAP2000 V.20. Integrated Finite Element Analysisand Design of Structures Basic Analysis Reference Manual, Computersand Structures Inc., Berkeley, CA, USA.

15. KYPTTE, 2016. Kiyı Yapıları Planlama ve Tasarım Teknik Esasları, Ankara. 
